\title{
Faktor-Faktor yang Mempengaruhi Kemiskinan di 9 (Sembilan) Kota di Provinsi Jawa Timur
}

\author{
Renta Yustie \\ Prodi Ekonomi Pembangunan, FEB, Universitas Wijaya Kusuma Surabaya \\ Email: rentayustie@uwks.ac.id
}

\begin{tabular}{l}
\hline Article Info \\
\hline Article history: \\
Published: Dec 25, 2020 \\
Page: $1-9$ \\
\hline
\end{tabular}

Keyword:

Poverty, Human

Development Index (HDI),

Dependency Ratio, Open

Unemployment Rate, Panel.

\section{Pendahuluan}

Kemiskinan dipandang sebagai kondisi anggota masyarakat yang tidak atau belum mampu turut serta dalam proses perubahan, karena tidak mempunyai

\section{Editorial Office:}

Prodi Ilmu Ekonomi Fakultas Ekonomi dan Bisnis Islam, UIN Sunan Ampel Surabaya Jl. Ahmad Yani 117 Surabaya, Jawa Timur 60237, Indonesia.

Email: oje@uinsby.ac.id
Penelitian ini bertujuan untuk menganalisis pengaruh dari indeks pembangunan manusia (IPM), rasio ketergantungan dan tingkat pengangguran terbuka (TPT) terhadap kemiskinan secara parsial dan simultan. Data yang digunakan berupa data sekunder tentang kemiskinan, indeks pembangunan manusia (IPM), rasio ketergantungan, tingkat pengangguran terbuka (TPT) dimana semua data dalam satuan persen (\%). Metode yang digunakan yaitu metode panel dengan analisis regresi linier berganda. Hasil penelitian menyatakan bahwa variabel indeks pembangunan manusia (IPM), rasio ketergantungan dan tingkat pengangguran terbuka (TPT) memiliki pengaruh yang signifikan terhadap kemiskinan secara parsial dan simultan.

Kata Kunci : Kemiskinan, Indeks Pembangunan Manusia (IPM), Rasio Ketergantungan, Tingkat Pengangguran Terbuka (TPT), Panel.

This research aims to analyze effect from human development index (HDI), dependency ratio, open unemployment rate to poverty is partially and simultaneously. Data used in research is secondary data are poverty, human development index (HDI), dependency ratio, open unemployment rate overall in percentage (\%)., with used analyze of multiple linier regression methode. This result is human development index (HDI), dependency ratio, open unemployment rate have a effect to partially and simultaneously to poverty.

Keywords : Poverty, Human Development Index (HDI), Dependency Ratio, Open Unemployment Rate, Panel.

Copyright (C) 2020 OECONOMICUS Journal of Economics kemampuan, baik kemampuan dalam kepemilikan faktor produksi maupun kualitas faktor produksi yang memadai sehingga tidak mendapatkan manfaat dari hasil proses pembangunan (Arsyad, 2010). 
Ketidakmampuan masyarakat dalam memperoleh faktor produksi disebabkan oleh penghasilan atau upah yang diterima tidak cukup untuk memenuhi kebutuhan dasar hidup seseorang (Arsyad, 2010). Pengukuran kebutuhan dasar hidup seseorang dengan kemampuan konsumsi menggunakan garis kemiskinan konsumsi yang terdiri dari 1). pengeluaran yang diperlukan untuk membeli standar gizi minimum dan kebutuhan mendasar lainnya, 2). jumlah kebutuhan lain yang sangat bervariasi, yang mencerminkan biaya partisipasi dalam kehidupan masyarakat sehari-hari (Kuncoro, 2003). Garis kemiskinan di Indonesia per bulan rata-rata sebesar Rp. 454.652 yang diterima oleh per orang (BPS Jawa Timur, 2020).

Fenomena kemiskinan memiliki kaitan yang erat dengan kondisi kualitas sumberdaya manusia. Sumberdaya manusia seharusnya memiliki kualitas yang baik meliputi kualitas pendidikan, kesehatan dan penghasilan. Pengukuran tingkat kualitas sumberdaya manusia menggunakan indeks pembangunan manusia (IPM). Indeks pembangunan manusia merupakan indikator penting untuk mengukur keberhasilan dalam upaya membangun kualitas hidup masyarakat atau penduduk (BPS Jawa Timur, 2020). Indeks pembangunan manusia dapat menentukan peringkat atau level pembangunan suatu wilayah dan negara. Wilayah dengan jumlah penduduk yang cukup banyak rentan terhadap masalah kemiskinan. Laju pertumbuhan penduduk yang tinggi, disisi lain pendapatan per kapita rendah mengakibatkan semua pendapatan yang diterima habis untuk konsumsi tanpa ada tabungan (Jhingan, 2004). Kondisi tingginya pertumbuhan penduduk dan rendahnya pendapatan per kapita terjadi di wilayah perkotaan.

Perkotaan merupakan pusat pertumbuhan ekonomi dan pembangunan ekonomi tetapi tidak semua masyarakat perkotaan dapat menggunakan hasil dari pertumbuhan dan pembangunan ekonomi, hal ini yang menyebabkan kemiskinan di perkotaan cukup tinggi (Todaro, 2010). Ketidakmampuan menggunakan hasil pembangunan ekonomi berkaitan dengan tidak ada akses untuk menggunakan hasil pembangunan ekonomi karena tidak memiliki pekerjaan dan penghasilan yang rendah. Penduduk usia produktif seharusnya memiliki pekerjaan dan penghasilan tetapi karena jumlah tenaga kerja lebih banyak dari lapangan pekerjaan sehingga tidak semua terserap di lapangan pekerjaan maka bisa menimbulkan pengangguran (Jhingan, 2004). Persentase jumlah pengangguran terhadap jumlah angkatan kerja merupakan tingkat pengangguran terbuka (BPS Jawa Timur, 2020).

Penduduk usia produktif yang bekerja di perkotaan ada yang bekerja paruh waktu dan penuh waktu. Pekerja paruh waktu biasanya tidak memiliki penghasilan sesuai upah minimum perkotaan, sedangkan pekerja penuh waktu memiliki penghasilan sebesar upah minimum perkotaan. Penduduk usia produktif yang bekerja baik paruh waktu dan penuh waktu menanggung penduduk usia tidak produktif. Perbandingan antara jumlah penduduk umur 0-14 tahun dan umur 65 tahun ke atas (kedua umur tersebut bukan sebagai angkatan kerja) sebagai penduduk usia tidak produktif terhadap penduduk usia 15-65 tahun usia produktif disebut dengan rasio ketergantungan (BPS Jawa Timur, 2010). Rasio ketergantungan di perkotaan cukup tinggi karena angka kelahiran tinggi dan angka kematian rendah sehingga banyak penduduk perkotaan memiliki usia panjang tetapi tidak termasuk dalam usia produktif lagi (Simanjuntak, 1998).

Masalah kemiskinan yang ada di perkotaan dengan beberapa faktor penyebabnya dapat dirumuskan dalam bentuk rumusan masalah untuk diteliti lebih lanjut yaitu:

1. Apakah faktor-faktor penyebab kemiskinan yaitu indeks pembangunan manusia (IPM), rasio 
ketergantungan, tingkat pengangguran terbuka (TPT) memiliki pengaruh secara parsial terhadap kemiskinan di 9 (sembilan) kota di Provinsi Jawa Timur tahun 2015-2019?

2. Apakah faktor-faktor penyebab kemiskinan yaitu indeks pembangunan manusia (IPM), rasio ketergantungan, tingkat pengangguran terbuka (TPT) memiliki pengaruh secara simultan terhadap kemiskinan di 9 (sembilan) kota di Provinsi Jawa Timur tahun 2015-2019?

Tujuan mengetahui dan menganalisis masalah kemiskinan di perkotaan untuk melihat seberapa jauh hasil pembangunan di perkotaan dapat digunakan penduduk. Melihat pertumbuhan pendapatan per kapita masyarakat di perkotaan untuk mengurangi kemiskinan.

\section{Kajian Pustaka}

Masyarakat miskin selalu berada pada kondisi ketidakberdayaan dan ketidakmampuan mereka dalam hal memenuhi kebutuhan dasar hidup yaitu 1). melakukan kegiatan usaha produktif, 2). menjangkau akses sumberdaya sosialekonomi, 3). menentukan nasibnya sendiri dan senantiasa mendapatkan perlakuan diskriminasi, 4). memiliki martabat dan harga diri yang rendah (Arsyad, 2010). Masyarakat miskin adalah masyarakat yang tidak memiliki akses ke aspek politik, aspek sosial, aspek ekonomi dan aspek budaya serta nilai. Penyebab kemiskinan dapat terjadi secara absolut berupa kemiskinan yang dibawa sejak lahir dan kemiskinan relatif berupa kemiskinan berdasarkan atas penghasilan yang diterima (BPS Jawa Timur, 2020). Kondisi kemiskinan membawa pada kualitas sumberdaya manusia yang kurang baik.

Kualitas sumberdaya manusia yang diukur dengan indeks pembangunan manusia (IPM) menggunakan 3 (tiga) ukuran suatu pembangunan sumberdaya manusia. Ukuran pada indeks pembangunan manusia (IPM) yaitu 1). usia panjang yang diukur dengan angka harapan hidup dengan faktor kesehatan, 2). pengetahuan yang diukur dengan rata-rata penduduk usia sekolah yang menjalani sekolah secara formal dengan faktor pendidikan, 3). penghasilan yang diukur dengan pendapatan per kapita dengan faktor daya beli masyarakat (Kuncoro, 2003). Kondisi indeks pembangunan manusia (IPM) yang berkualitas baik akan menciptakan tenaga kerja yang dapat bekerja dengan baik sehingga mengurangi pengangguran pada tenaga kerja di usia produktif.

Pengangguran terjadi karena jumlah penduduk meningkat dengan cepat dan lapangan pekerjaan tidak bertambah secara cepat dan banyak. Penduduk yang meningkat jumlahnya dengan cepat dan banyak tidak diikuti dengan peningkatan lapangan pekerjaan maka akan mengurangi jumlah pendapatan, tabungan dan investasi (Jhingan, 2004). Banyaknya pengangguran tentu menjadi beban sosial dan ekonomi suatu daerah, karena menyebabkan masalah baru muncul seperti kriminal, kelaparan, tuna wisma (Todaro, 2010). Thomas R. Malthus menyatakan pentingnya pengendalian jumlah pertumbuhan penduduk di perkotaan untuk pemerataan pendapatan per kapita dan pemerataan penggunaan hasil pembangunan di kota bagi masyarakat kota (Todaro, 2010). Pengendalian pertumbuhan penduduk di perkotaan dengan keluarga berencana dan transmigrasi ke daerah pedalaman dan terluar yang membutuhkan penduduk dan tenaga kerja (BPS Jawa Timur, 2020).

Erwan (2007) menyatakan kegagalan mengatasi persoalan kemiskinan akan dapat menyebabkan munculnya berbagai persoalan sosial, ekonomi dan politik di tengah-tengah masyarakat. Sumber kekayaan alam yang melimpah bukan menjadi jaminan bahwa penduduknya juga akan kaya. Selama ini kebijakan dan 
program pengentasan kemiskinan telah banyak dilakukan oleh pemerintah. Program-program tersebut antara lain adalah Kredit Investasi Kecil (KIK), Kredit Usaha Tani (KUT), Kredit Modal Permanen (KMP), Kredit Usaha Kecil (KUK) dan Inpress Desa Tertinggal (IDT).

Nunung (2008) mengatakan bahwa kemiskinan seringkali ditandai dengan tingginya tingkat pengangguran dan keterbelakangan. Masyarakat miskin umumnya lemah dalam kemampuan berusaha dan terbatas aksesnya terhadap kegiatan ekonomi sehingga akan tertinggal jauh dari masyarakat lainnya yang mempunyai potensi lebih tinggi. Ukuran kemiskinan dilihat dari tingkat pendapatan dapat dikelompokkan menjadi kemiskinan absolut dan kemiskinan relatif. Faktor-faktor yang menyebabkan timbulnya kemiskinan diantaranya; rendahnya tingkat pendidikan, rendahnya derajat kesehatan, terbatasnya lapangan kerja, dan kondisi keterisolasian.

Debrina (2018) menjelaskan bahwa upaya pengentasan kemiskinan terdapat dua strategi yang harus di tempuh. Pertama, melindungi keluarga dan kelompok masyarakat miskin melalui pemenuhan kebutuhan mereka dari berbagai bidang. Kedua, melakukan pelatihan kepada mereka agar mempunyai kemampuan untuk melakukan usaha pencegahan terjadinya kemiskinan baru. Salah satu aspek penting untuk mendukung strategi penanggulangan kemiskinan adalah tersedianya data kemiskinan yang akurat. Ketika data telah tersedia, maka pemerintah dapat mengambil keputusan apa saja yang harus dilakukan untuk penanggulangan tersebut. Selain itu, data yang tersedia dapat membuat pemerintah membandingkan angka kemiskinan dari tahun ke tahun.

Elvira (2018) menyatakan bahwa penanggulangan kemiskinan yang selama ini dilakukan oleh pemerintah ternyata belum dapat mencapai hasil yang optimal. Jumlah penduduk miskin memang telah dapat dikurangi secara berarti akan tetapi dari jumlahnya masih cukup besar. Secara kualitas, kehidupan rumah tangga miskin nyaris tidak mengalami perubahan karena masih saja bersifat subsisten dan inevolutif. Hal ini disebabkan oleh penyeragaman kebijakan dalam memecahkan permasalahan kemiskinan yang dihadapi pada setiap daerah. Padahal setiap daerah mempunyai karakteristik yang berbeda, baik sumber daya alam, sumber daya manusia maupun budaya. Dengan demikian upaya penanggulangan kemiskinan pada setiap daerah tentu membutuhkan pendekatan yang berbeda pula.

Afifatuz (2019) menjelaskan kemiskinan merupakan salah satu indikator untuk melihat keberhasilan pembangunan di suatu negara. Tingkat kemiskinan yang rendah menandakan program pembangunan telah berhasil dan secara langsung dapat meningkatkan kesejahteraan hidup masyarakat. Kemiskinan merupakan masalah multidimensi, dimana banyak faktor yang mempengaruhinya mulai dari pengangguran, upah minimum dan hingga perlambatan laju pertumbuhan ekonomi. Penduduk miskin adalah penduduk yang memiliki rata-rata pengeluaran per kapita per bulan di bawah garis kemiskinan. Berdasarkan data dari Badan Pusat Statistik (BPS), jumlah penduduk miskin perkotaan dan perdesaan di Indonesia cenderung terus menurun sejak tahun 2006 dan pada tahun 2017 mengalami penurunan yang cukup besar. Hal ini tentu saja merupakan suatu pertanda yang baik karena artinya perekonomian Indonesia mengalami penguatan.

Hipotesis yang dinyatakan pada penelitian ini adalah 1). Menduga ada pengaruh variabel indeks pembangunan manusia (IPM), rasio ketergantungan dan tingkat pengangguran terbuka (TPT) secara parsial terhadap kemiskinan di 9 (sembilan) kota di Provinsi Jawa Timur tahun 20152019 dan 2). Menduga ada pengaruh variabel indeks pembangunan manusia (IPM), rasio ketergantungan dan tingkat 
pengangguran terbuka (TPT) secara simultan terhadap kemiskinan di 9 (sembilan) kota di Provinsi Jawa Timur tahun 2015-2019.

\section{Metode Penelitian}

Penelitian ini merupakan penelitian kuantitatif karena menggunakan data yang terukur dan diperoleh dalam satuan angka. Penelitian ini menggunakan penjelasan secara deskriptif analisis yaitu menjelaskan hasil analisis secara deskriptif berupa penjelasan narasi terhadap data yang telah diperoleh dan telah diolah dengan alat analisis. Data sekunder digunakan dalam penelitian ini, dimana data sekunder diperoleh dari BPS Jawa Timur secara online melalui website BPS Jawa Timur.

Variabel yang digunakan dalam penelitian adalah variabel bebas (independent variable) terdiri dari indeks pembangunan manusia (IPM), rasio ketergantungan, tingkat pengangguran terbuka (TPT). Selanjutnya variabel terikat (dependent variable) yaitu kemiskinan. Tahun penelitian sebagai kurun waktu penelitian ini adalah selama 5 (lima) tahun terdiri dari tahun 2015 sampai dengan tahun 2019.

Populasi dalam penelitian adalah 38 kabupaten dan kota di Provinsi Jawa Timur, tetapi tidak semua populasi digunakan dalam penelitian, hanya mengambil beberapa sampel dari sebagian populasi untuk diteliti. Wilayah atau daerah penelitian dan sekaligus sebagai sampel dalam penelitian meliputi 9 (sembilan) kota di Provinsi Jawa Timur.

Model analisis yang digunakan dalam penelitian ini adalah model analisis regresi linier berganda. Metode yang digunakan adalah metode data panel karena meliputi rentang waktu dan rentang tempat (ruang) dalam penelitian. Alat analisis yang digunakan untuk mengolah data di penelitian ini adalah EViews 6. Bentuk model analisis dalam penelitian ini adalah sebagai berikut:
$K_{i t}=\propto_{0}+\propto_{1} I P M_{i t}+\propto_{2} R K_{i t}+\propto_{3} T P T_{i t}+\varepsilon_{i t}$

Keterangan Model:

$\mathrm{K}=$ Kemiskinan $(\%)$ di Provinsi Jawa Timur IPM = Indeks Pembangunan Manusia (\%) di Provinsi Jawa Timur

RK = Rasio Ketergantungan (\%) di Provinsi Jawa Timur

TPT $=$ Tingkat Pengangguran Terbuka (\%) di Provinsi Jawa Timur

$\propto_{0}=$ koefisien regresi konstanta

$\propto_{1}=$ koefisien regresi IPM

$\propto_{2}=$ koefisien regresi RK

$\propto_{3}=$ koefisien regresi TPT

$i=$ cross section, 9 kota di Provinsi Jawa

Timur

$t=$ time serries, tahun 2015-2019

$e=$ error term

Teknik pengukuran pada pengolahan data menggunakan pengujian statistik digunakan uji $F$, uji-t, uji koefisien determinasi $\left(R^{2}\right)$.

\section{Hasil dan Pembahasan}

Kemiskinan di 9 (sembilan) kota di Provinsi Jawa Timur dipengaruhi oleh indeks pembangunan manusia, rasio ketergantungan dan tingkat pengangguran terbuka. Hasil regresi linier berganda pada Tabel 1:

\section{Tabel 1. Hasil Uji Regresi Linier} Berganda

\begin{tabular}{|c|c|c|c|c|}
\hline Var & Coeff & $\begin{array}{c}\text { Std. } \\
\text { Error }\end{array}$ & $\begin{array}{c}\mathrm{t}- \\
\text { Statistic }\end{array}$ & Prob \\
\hline C & 48.61376 & 7.262 & 4.063 & 0.0001 \\
IPM & -0.115173 & 0.023 & -3.125 & 0.0017 \\
RK & 3.629652 & 0.128 & 2.783 & 0.0005 \\
TPT & 2.884648 & 0.418 & 1.527 & 0.0024 \\
\hline
\end{tabular}

Sumber: diolah dengan Eviews 6, tahun 2020.

Tabel 1 menunjukan bahwa semua variabel bebas yaitu indeks pembangunan manusia (IPM), rasio ketergantungan (RK) dan tingkat pengangguran terbuka (TPT) memiliki pengaruh yang signifikan dengan nilai probabilitas dibawah nilai alfa / derajat keyakinan sebesar $(5 \%=0,05)$. Sehingga hasil analisis regresi linier berganda jika dimasukan kedalam model menjadi: 
$K_{i t}=\propto_{0}+\propto_{1} I P M_{i t}+\propto_{2} R K_{i t}+\propto_{3} T P T_{i t}+\varepsilon_{i t}$ $K_{i t}=48.61376-0.115173$ IPMit + 3.629652RKit $+2.884648 \mathrm{TPTit}+\varepsilon_{i t}$

Uji F secara simultan variabel bebas yaitu indeks pembangunan manusia (IPM), rasio ketergantungan (RK) dan tingkat pengangguran terbuka (TPT) terhadap kemiskinan $(\mathrm{K})$ pada Tabel 2.

Tabel 2. Uji F (simultan)

\begin{tabular}{|c|c|}
\hline Variabel & Nilai Probabilitas F \\
\hline IPM & 0.0000 \\
RK & 0.0000 \\
TPT & 0.0000 \\
\hline
\end{tabular}

Sumber: diolah dengan Eviews 6, tahun 2020.

Tabel 2 Uji F (simultan) diperoleh nilai probabilitas $\mathrm{F}$ sebesar 0.000000 yang lebih kecil dari nilai $\alpha$. Nilai $\alpha$ yang digunakan sebesar $5 \%$ atau $(0.0000<0.05)$, maka dinyatakan bahwa variabel bebas yaitu indeks pembangunan manusia (IPM), rasio ketergantungan (RK) dan tingkat pengangguran terbuka (TPT) secara simultan berpengaruh signifikan terhadap kemiskinan (K).

Uji-t secara parsial variabel bebas yaitu indeks pembangunan manusia (IPM), rasio ketergantungan (RK) dan tingkat pengangguran terbuka (TPT) terhadap kemiskinan $(\mathrm{K})$ pada Tabel 3.

Tabel 3. Uji-t (parsial)

\begin{tabular}{|c|c|c|}
\hline Variabel & $\begin{array}{c}\text { Nilai } \\
\text { Probabilitas-t }\end{array}$ & $\begin{array}{c}\text { Nilai }(\propto \\
=5 \%= \\
0.05)\end{array}$ \\
\hline IPM & 0.0017 & 0.05 \\
RK & 0.0005 & 0.05 \\
TPT & 0.0024 & 0.05 \\
\hline
\end{tabular}

Sumber: diolah dengan Eviews 6, tahun 2020.

Tabel. 3 Uji-t (parsial) menjelaskan bahwa variabel bebas yaitu indeks pembangunan manusia (IPM), rasio ketergantungan (RK) dan tingkat pengangguran terbuka (TPT) memiliki nilai probabilitas-t yang kurang dari nilai $\propto$ sebesar $5 \%=0.05$. Sehingga ketiga variabel bebas yaitu indeks pembangunan manusia (IPM), rasio ketergantungan (RK) dan tingkat pengangguran terbuka (TPT) memiliki pengaruh secara parsial terhadap kemiskinan (K).

Uji koefisien determinasi $\left(R^{2}\right)$ pada penelitian ini dijelaskan pada Tabel.4 untuk melihat seberapa besar pengaruh variabel bebas yaitu indeks pembangunan manusia (IPM), rasio ketergantungan (RK) dan tingkat pengangguran terbuka (TPT) memiliki pengaruh terhadap kemiskinan (K). Dan sisanya dipengaruhi oleh variabel lain diluar variabel bebas yang digunakan dalam penelitian ini.

Tabel 4. Uji Koefisien Determinasi $\left(\boldsymbol{R}^{\mathbf{2}}\right)$

\begin{tabular}{c|c} 
Koefisien & 0.8874913 \\
Determinasi $\left(R^{2}\right)$ & \\
\hline
\end{tabular}

Sumber: diolah dengan Eviews 6, tahun 2020.

\section{Pembahasan}

Variabel indeks pembangunan manusia (IPM) secara signifikan berpengaruh terhadap kemiskinan. Mekanisme pengaruhnya berupa peningkatan kualitas pada manusia seperti kemampuan membaca, menulis dan menempuh pendidikan formal. Selanjutnya dilihat dari besarnya penghasilan yang diterima oleh individu, penghasilan yang diterima harus dapat digunakan untuk memenuhi kebutuhan standar hidup dan sisanya untuk tabungan dan investasi. Jika individu memiliki penghasilan maka setidaknya dapat mengakses fasilitas kesehatan yang disediakan pemerintah. Kesehatan merupakan bagian penting dari kualitas sumberdaya manusia. Manusia yang sehat akan menjadi tenaga kerja yang lebih produktif dan sehingga dapat meningkatkan produktivitas bekerja dan mengurangi harihari sakit.

Di perkotaan kualitas manusia sangat berpengaruh pada perekonomian, kualitas manusia yang baik akan meningkatkan hasil pembangunan dan perekonomian sehingga secara tidak langsung mengurangi kemiskinan di perkotaan. 
Tabel 5. Indeks Pembangunan Manusia (IPM) di 9 (sembilan) kota di Provinsi Jawa Timur

\begin{tabular}{|l|c|c|c|c|c|}
\hline Kota & 2015 & 2016 & 2017 & 2018 & 2019 \\
\hline Ked & 75,67 & 76,33 & 77,13 & 77,58 & 78,08 \\
\hline Blitar & 76,00 & 76,71 & 77,10 & 77,58 & 78,56 \\
\hline Mlng & 80,05 & 80,46 & 80,65 & 80,89 & 81,32 \\
\hline Prob & 71,01 & 71,50 & 72,09 & 72,53 & 73,27 \\
\hline Pasrn & 73,78 & 74,11 & 74,39 & 74,78 & 75,25 \\
\hline Mjkt & 75,54 & 76,38 & 76,77 & 77,14 & 77,96 \\
\hline Mad & 79,48 & 80,01 & 80,13 & 80,33 & 80,88 \\
\hline Sby & 79,47 & 80,38 & 81,07 & 81,74 & 82,22 \\
\hline Batu & 72,62 & 73,57 & 74,26 & 75,04 & 75,88 \\
\hline
\end{tabular}

Sumber: BPS Provinsi Jawa Timur, Tahun 2020

Langkah yang dilakukan agar indeks pembangunan manusia (IPM) terus meningkat adalah menyediakan kemudahan akses kesehatan melalui puskesmas dan posyandu serta rumah sakit daerah pemerintah dengan memanfaatkan kartu BPJS Kesehatan. Langkah selanjutnya adalah menyediakan pendidikan bagi masyarakat tidak mampu melalui sekolah inpres dan bantuan biaya pendidikan, serta memberikan bantuan langsung tunai untuk masyarakat miskin di perkotaan.

Variabel rasio ketergantungan memiliki pengaruh signifikan terhadap kemiskinan di perkotaan. Kota merupakan tempat laju pertumbuhan penduduk yang cukup tinggi dan kota sebagai pusat pembangunan ekonomi dan pertumbuhan ekonomi. Penduduk usia produktif di perkotaan sebaiknya harus terserap ke lapangan pekerjaan untuk mendapatkan penghasilan sehingga meningkatkan pendapatan per kapita masyarakat perkotaan. Penduduk usia produktif menanggung penduduk usia tidak produktif secara perhitungan rasio ketergantungan. Penduduk usia tidak produktif yang tinggal di perkotaan cukup banyak sehingga besar rasio ketergantungan penduduk usia tidak produktif terhadap penduduk usia produktif cukup tinggi, dalam jangka panjang maka dapat meningkatkan kemiskinan di perkotaan.
Besarnya laju pertumbuhan penduduk usia produktif di perkotaan harus seimbang dengan laju pertumbuhan lapangan pekerjaan di perkotaan.

Tabel 6. Rasio Ketergantungan di 9 (sembilan) kota di Provinsi Jawa Timur

\begin{tabular}{|l|c|c|c|c|c|}
\hline Kota & 2015 & 2016 & 2017 & 2018 & 2019 \\
\hline Kediri & 40,28 & 40,03 & 39,84 & 39,73 & 39,67 \\
\hline Blitar & 45,17 & 44,92 & 44,73 & 44,64 & 44,61 \\
\hline Malang & 37,13 & 36,92 & 36,76 & 36,67 & 36,64 \\
\hline Probolinggo & 44,19 & 43,90 & 43,65 & 43,49 & 43,39 \\
\hline Pasuruan & 44,12 & 43,81 & 43,54 & 43,36 & 43,22 \\
\hline Mojokerto & 42,14 & 41,86 & 41,64 & 41,51 & 41,42 \\
\hline Madiun & 42,31 & 42,08 & 41,93 & 41,87 & 41,88 \\
\hline Surabaya & 36,58 & 36,35 & 36,17 & 36,04 & 35,96 \\
\hline Batu & 44,06 & 43,84 & 43,66 & 43,57 & 43,56 \\
\hline
\end{tabular}

Sumber: BPS Provinsi Jawa Timur, Tahun 2020

Pemerintah memberikan bantuan sosial bagi penduduk usia tidak produktif berupa bantuan langsung tunai dan bantuan sembako serta rumah susun. Pemerintah membuka lapangan pekerjaan bagi penduduk usia produktif sesuai dengan jenjang pendidikan dan ketrampilan yang dimiliki.

Variabel tingkat pengangguran terbuka (TPT) memiliki pengaruh signifikan terhadap kemiskinan. Penduduk yang menganggur tentu tidak memiliki penghasilan tetap untuk memenuhi kebutuhan dasar hidup. Penduduk yang menganggur disebabkan oleh beberapa sebab yaitu ketidaksesuaian bidang keahlian terhadap lapangan pekerjaan yang tersedia dan akibat adanya pemutusan hubungan kerja serta tidak bekerja secara sukarela karena merasa putus asa. Pengangguran dalam jumlah cukup besar terutama di perkotaan memiliki dampak negatif yang cukup besar yaitu meningkatkan kriminalitas dan kemiskinan secara jangka panjang.

Pemerintah memiliki fokus perhatian lebih pada masalah pengangguran di perkotaan karena kota merupakan pusat pertumbuhan dan pembangunan ekonomi 
sehingga seharusnya angka pengangguran dan kemiskinan bisa rendah.

Tabel 7. Tingkat Pengangguran Terbuka di 9 (sembilan) kota

di Provinsi Jawa Timur

\begin{tabular}{|l|c|c|c|c|c|}
\hline Kota & 2015 & 2016 & 2017 & 2018 & 2019 \\
\hline Kediri & 8,46 & 7,66 & 4,68 & 3,63 & 4,22 \\
\hline Blitar & 3,80 & 5,71 & 3,76 & 4,06 & 4,64 \\
\hline Malang & 7,38 & 7,22 & 7,22 & 6,79 & 6,04 \\
\hline Prob & 4,01 & 5,16 & 3,42 & 3,64 & 4,41 \\
\hline Pasuruan & 5,57 & 6,09 & 4,64 & 4,55 & 5,06 \\
\hline Mojokerto & 4,88 & 4,42 & 3,61 & 2,45 & 2,65 \\
\hline Madiun & 5,10 & 6,93 & 4,26 & 3,85 & 4,01 \\
\hline Surabaya & 7,01 & 5,82 & 5,98 & 6,12 & 5,87 \\
\hline Batu & 4,29 & 2,42 & 2,26 & 3,12 & 2,48 \\
\hline
\end{tabular}

Sumber: BPS Provinsi Jawa Timur, Tahun 2020

Langkah yang dilakukan oleh pemerintah adalah 1). membuka lapangan kerja yang sebanyak mungkin, 2). meningkatkan modal usaha bagi wirausaha di kota, 3). menempatkan pencari kerja sesuai dengan keahlian dan ketrampilan, 4). memberikan pelatihan bagi pencari kerja untuk melatih jiwa wirausaha (entrepreuner) untuk membuka lapangan pekerjaan baru. Untuk meningkatkan lapangan pekerjaan tentunya pemerintah bekerja sama dengan investor luar negeri agar mau membuka usaha di dalam negeri untuk membantu menyerap tenaga kerja di dalam negeri.

\section{Kesimpulan}

Kesimpulan pada penelitian ini menjelaskan bahwa kemiskinan di perkotaan akan tetap ada tetapi dapat dikurangi porsinya secara berkala dengan menerapkan beberapa cara yang dilakukan oleh pemerintah. Langkah mengurangi kemiskinan adalah 1). memperbarui data penduduk melalui survey penduduk, 2). mengawasi penyaluran bantuan sosial dan bantuan langsung tunai agar tepat sasaran ke masyarakat miskin dan berpenghasilan rendah, 3). mengurangi konsumsi bagi masyarakat miskin dan masyarakat berpenghasilan rendah dalam artian menghemat pengeluaran untuk konsumsi bukan kebutuhan pokok, 4). bantuan di bidang pertanian, peternakan dan perikanan, 5). alokasi pengeluaran untuk program pengentasan kemiskinan secara tepat sasaran dan sesuai prosedur.

Pemerintah sebagai penggerak masyarakat sebaiknya selalu memperbarui data kependudukan dan data sosial ekonomi lainnya melalui sensus yang dilakukan secara rutin dan berkala. Tujuan dari adanya data kependudukan dan data sosial ekonomi maka akan membantu kerja pemerintah dalam membuat dan mengambil serta menetapkan kebijakan terkait kependudukan dan sosial ekonomi. Data tersebut membantu pula untuk pemerintah dalam menerapkan program mengatasi kemiskinan di perkotaan di Provinsi Jawa Timur. Tentunya tidak hanya pemerintah tetapi diperlukan kerjasama dari masyarakat yang terdampak dan rentan akan kemiskinan.

\section{Daftar Pustaka}

Agus, Erwan Purwanto. "Mengkaji Potensi Usaha Kecil dan Menengah (UKM) Untuk Pembuatan Kebijakan Anti Kemiskinan di Indonesia". Jurnal Ilmu Sosial dan Ilmu Politik Volume 10, Nomor 3, Maret 2007 (295-324).

Arsyad, Lincolin. Ekonomi Pembangunan. Yogyakarta: UPP STIM YKPN Yogyakarta, 2010.

BPS. Jawa Timur Dalam Angka 2010. Jawa Timur: BPS, 2010.

-----. Jawa Timur Dalam Angka 2020. Jawa Timur: BPS, 2020.

Handayani, Elvira Jacobus, Paulus Kindangen, Een N Walewangko. "Analisis Faktor-Faktor Yang Mempengaruhi Kemiskinan Rumah Tangga di Sulawesi Utara." Jurnal Ekonomi Pembangunan Ekonomi dan Keuangan Daerah Vol.19, No.7, 2018. 
Jhingan, ML. Ekonomi Pembangunan dan Perencanaan. Jakarta: RajaGrafindo Persada, 2004.

Kuncoro, Mudrajad. Ekonomi Pembangunan Teori Masalah dan Kebijakan. Yogyakarta: UPP AMP YKPN, 2003.

Nurwati, Nunung. "Kemiskinan : Model Pengukuran, Permasalahan dan Alternatif Kebijakan". Jurnal Kependudukan Padjadjaran Vol. 10, No.01, Januari 2018 (1-11).

Simanjuntak, J Payaman. Pengantar Ekonomi Sumber Daya Manusia. Jakarta: LPFE-UI, 1998.

Todaro, P. Michael dan Stephen C. Smith. Pembangunan Ekonomi. Jakarta: Erlangga, 2010.

Vita, Debrina Ferezagia. “Analisis Tingkat Kemiskinan di Indonesia”. Jurnal Sosial Humaniora Terapan Volume 1, Nomor 1, Juli Desember 2018.

Zahra, Afifatus, Aulia Fatin A, Hanifah Afuwu, Rintan Aulia R. "Struktur Kemiskinan Indonesia Berapa Besar Pengaruh Kesehatan, Pendidikan dan Kelayakan Hunian ?’. Jurnal Inovasi Ekonomi Vol. 04, No.02 September 2019 (67-74). 